\section{Hairy Tongue: Differential Diagnosis by Use of Widefield Optical Fluorescence}

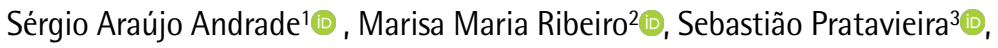

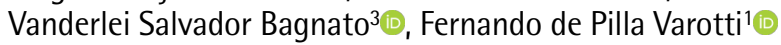

'Núcleo de Pesquisa em Química Biológica (NQBio), UFSJ Universidade Federal de São João Del Rei, Divinópolis, MG, Brasil ${ }^{2}$ Service of Dental Specialties, Prefeitura Municipal de Divinópolis, Divinópolis, MG, Brasil

${ }^{3}$ Optics and Photonics Research Center (CEPOF), IFSC - Instituto de Física, Universidade de São Paulo, São Carlos, SP, Brasil

Correspondence: Sérgio Araújo Andrade, Av. Sebastião Gonçalves Coelho, 400, 35501-296 Divinópolis, MG, Brasil. Tel: +55-37-3221-4657. E-mail saandrade@ufsj.edu.br
Key Words: hairy tongue, differential diagnosis, fluorescence image

\section{Introduction}

The tongue can be affected by pathologies of different etiologies: inflammatory, infectious, neoplastic or even systemic (1-3). In this sense, it represents the site of the oral cavity with the highest incidence of squamous cell carcinoma, which, is a pathology of high morbimortality (4). Otherwise, the tongue can also be affected by benign conditions of excellent prognoses, such as hairy tongue with a prevalence ranging from 0.5 to $11.3 \%$ (1).

The establishment of a precise differential diagnosis remains a challenge. In initial stages, hairy tongue presents similarity of signs, symptoms and risk factors with pathologies of different etiologies.

Hairy tongue is an acquired benign pathology. Clinically, is characterized by hairlike projections, which, are due to the presence of elongated and hypertrophied filiform papillae. It usually occurs in the two-thirds anterior to the circumvallated papillae on the dorsal tongue surface $(1-3,5-7)$. Thus, the normal length of the filiform papillae is $1 \mathrm{~mm}$ and, in the hairy tongue, exceeds $3 \mathrm{~mm}(1,5)$. This growth is due to a decrease in the desquamation of cells, reducing debridement and leading to the accumulation of keratinized layers $(1-3,5-7)$. The color of the tongue in the region can be: unpigmented, white, tan, bluish, yellowish, green, brown or black, of the latter, when present, originates the denomination black hairy tongue $(1-3,5-9)$.
Thus, in hairy tongue, the color will be determined by an extrinsic factor adhered to the lingual surface, such as: tobacco, coffee, black tea, medications or chromogenic microorganisms that produce porphyrin (1-3,5,7-9). Generally, it is asymptomatic bringing, however, aesthetic concern (1,3,5-7). Nevertheless, patients may report nausea, metallic taste, dysgeusia, burning mouth sensation, and halitosis $(3,5,6)$.

The diagnosis of hairy tongue is clinical $(1,5)$. Patients generally report smoking and poor oral hygiene $(1-3,5,6)$ However, the use of antibiotics (penicillin, aureomycin, erythromycin, doxycycline and neomycin), candidiasis, alcohol, and dentures are associated with this pathology $(1,2,5,6)$. Clinically, the main feature to be observed are lesions that can be scraped off $(1,5)$. The differential diagnosis applied when hairy tongue exhibits whitish plaques includes oral hairy leukoplakia, potentially malignant leukoplakia and squamous cell carcinoma (1-3,57,10-16) (Table 1). The treatment consists of modifying the predisposing factors through the reduction of smoking and implementation of adequate oral hygiene with brushing the tongue through scraper and soft toothbrush associated with dentifrice $(1,2,5-8)$. However, in persistent cases, topical retinoids, antifungals or keratolytics drugs may be used $(1,5)$. Incisional biopsy and laboratory tests for fungi, viruses and bacteria can be indicated, in case of doubts of the 
physician or dentists, about the final diagnosis $(1,5)$. Thus, the use of noninvasive complementary examinations such as widefield optical fluorescence could provide additional data in clinical diagnosis, avoiding pain and anxiety to the patient with biopsy.

Widefield optical fluorescence devices have been broadly employed within the context of the screening and diagnosis of oral cancer and its precursor lesions (3,17-19). Indeed, this technology is approved by US FDA as a complementary examination to the traditional clinical examination to improve the visualization of oral pathologies, including oral cancer, which could be imperceptible to the naked eye. Furthermore, this technical is used to determine adequate margins in oral cancer surgeries $(17,19,20)$. However, our research group has expanded the functionalities of widefield optical fluorescence in the context of oral cancer or in other oral pathologies $(18,20)$.

Widefield optical fluorescence complementary examination allows the visualization of the autofluorescence produced by certain molecules, called fluorophores, which, are natural constituents of the tissue related to its structure or metabolism (17-19). Main fluorophores of the oral mucosa visualized by fluorescence examination $\vec{s}$ are the structural proteins like keratin and collagen; flavin adenine dinucleotide (FAD) involved in cell metabolism and porphyrins, which, may be related to both, bacterial and squamous cell carcinoma metabolism (17-20). Thus, any change in concentration and distribution of these fluorophores arising from a pathology can be detected and visualized through the widefield optical fluorescence device $(18,19)$. Widefield optical fluorescence technique has the advantages of being non-invasive, painless, without the need for dyes, no employing ionizing radiation and providing the result in real time $(18,20)$. Nevertheless, it requires a dark environment for accurate visualization of fluorescence, knowledge and professional training in the use of the technique.

In this work, we report differential diagnoses of the hairy tongue by using a complementary examination of widefield optical fluorescence.

\section{Case Report}

The widefield optical fluorescence complementary examination protocol involves a standard clinical examination consisting of anamnesis, general examination, extraoral and intraoral examination of the patient. Then, in the same dental consultation, the patient was examined with the widefield optical fluorescence device. Images related to clinical examination and fluorescence were obtained. This study has been approved by the Ethical Committee of Federal University of São João del-Rei, Campus CentroOeste Dona Lindu (CAAE: 59621516.8.0000.5545).

The clinical images were obtained through an intraoral camera model: DP6 Scope ${ }^{\circledR}$ (RF System Lab., Almere, Netherlands) connected to a computer. In turn, the widefield optical fluorescence complementary examination was performed with the EVINCE ${ }^{\circledR}$ device (MMOptics, São Carlos, SP, Brazil). Fluorescence images were obtained through Deluxe Handheld Digital Microscope ${ }^{\circledR}$ (Celestron LLC, Torrance, CA, USA) connected to EVINCE ${ }^{\circledR}$ and to a computer.

In February 2017, a 57-year-old man, was referred

Table 1. Clinical features for differential diagnosis of hairy tongue

\begin{tabular}{|c|c|}
\hline $\begin{array}{l}\text { Tongue } \\
\text { pathology }\end{array}$ & Clinical features \\
\hline $\begin{array}{l}\text { Hairy } \\
\text { tongue }\end{array}$ & $\begin{array}{l}\text { Presence of plaques whose color may vary from white, tan, bluish, yellowish, green brown or } \\
\text { black in the anterior two thirds of the tongue. An important feature is that the area of the lesion } \\
\text { can be scraped off }(1-3,5,6) \text {. The lesion is usually asymptomatic; however, the patient may report } \\
\text { complaints of metallic taste, dysgeusia, nausea, burning mouth and halitosis }(1,3,5,7,10) \text {. }\end{array}$ \\
\hline $\begin{array}{l}\text { Oral hairy } \\
\text { leukoplakia }\end{array}$ & $\begin{array}{l}\text { Presence of unilateral or bilateral, hairlike, white plaques on the lateral borders of the tongue }(3,5,6,11,12) \text {. } \\
\text { It is due to Epstein-Barr virus infection in immunosuppressed or immunocompromised patients }(3,5,6,11,12) \text {. } \\
\text { The plaques are adherent and, therefore, cannot be scraped off }(1,12) \text {. This pathology is usually asymptomatic } \\
(1,12) \text {. The gold-standard technique used for detecting the Epstein-Barr virus is in situ hybridization }(12) \text {. }\end{array}$ \\
\hline $\begin{array}{l}\text { Potentially } \\
\text { malignant } \\
\text { leukoplakia }\end{array}$ & $\begin{array}{l}\text { Presence of white adherent patch or plaques that can not scraped off }(3,6,11,13,14) \text {. Particular attention should } \\
\text { be given to the non-homogeneous leukoplakias nodular and verrucous types. Thus, tissue surface appearance } \\
\text { of verrucous leukoplakia is a whitish, exophytic, proliferative and rough }(3,13,14) \text {. While, nodular leukoplakia } \\
\text { is a small, round and white, exophytic tissue proliferation }(13,14) \text {. There may be reports of localized pain } \\
\text { or discomfort. There is a risk of malignant transformation of the lesions }(3,11,14) \text {. Biopsy and its respective } \\
\text { histopathological exam is the gold standard for establishing the final diagnosis of leukoplakia (3). }\end{array}$ \\
\hline $\begin{array}{l}\text { Squamous } \\
\text { cell } \\
\text { carcinoma }\end{array}$ & $\begin{array}{l}\text { In early stages may present as white patch or plaque, which, can develop nodularity or ulceration, usually on lateral or } \\
\text { ventral surface of the tongue }(3,6) \text {. This plaque cannot be scraped off. In this sense, verrucous carcinoma is a variant } \\
\text { of squamous cell carcinoma presenting a slow, rough, whitish, exophytic and locally destructive growth, with low risk } \\
\text { of metastasis }(15,16) \text {. Patient can reports presence of pain, ulcer, bleeding and loose teeth }(6,11,13,14) \text {. Biopsy and its } \\
\text { respective histopathological exam is the gold standard for establishing the final diagnosis of squamous cell carcinoma (3). }\end{array}$ \\
\hline
\end{tabular}


to the Dental Specialties Department of the Divinópolis Health Department (MG, Brazil) by a general dental practitioner with description of whitish exophytic growth on the dorsal surface of the tongue and, the diagnostic hypothesis of squamous cell carcinoma. The lesion had not been perceived by the patient and was identified by the general dental practitioner during consultation to making the complete denture. Subsequently, a dentist specialist in oral diagnosis, whose diagnostic hypothesis has been verrucous carcinoma, examined the patient. However, before performing an incisional biopsy, patient underwent, in the same consultation, to the complementary examination of widefield optical fluorescence.

In anamnesis, the patient did not report any symptomatology related to the lesion region or to the oral cavity. In addition, patient answered negatively about habits of ingesting alcoholic beverages, the presence of systemic pathologies, being in health treatment or taking medication. However, reported smoking 30 cigarettes per day for 35 years.

In general and extra oral clinical examination, no evidence of pathologies or lymph nodes involvement was found. During intraoral clinical examination, a white plaque with brownish areas was visualized on the dorsal surface of the tongue, anterior to the circumvallated papillae (Fig. 1A). No other lesions were found in the oral cavity. However, the presence of complete dentures and poor oral hygiene were verified.

Under Widefield optical fluorescence complementary examination, lesion site in dorsal tongue surface presented intense bright green fluorescence with projections of hairlike appearance. No site of higher decrease or loss of fluorescence, characterized by a darkened region in the image, was identified (Fig. 1B).

In addition, a tongue scraping with surgical gauze was performed, which, immediately, resulted in an improvement of the appearance with reduction of the whitish plaque. Furthermore, it was possible to visualize some fungiform
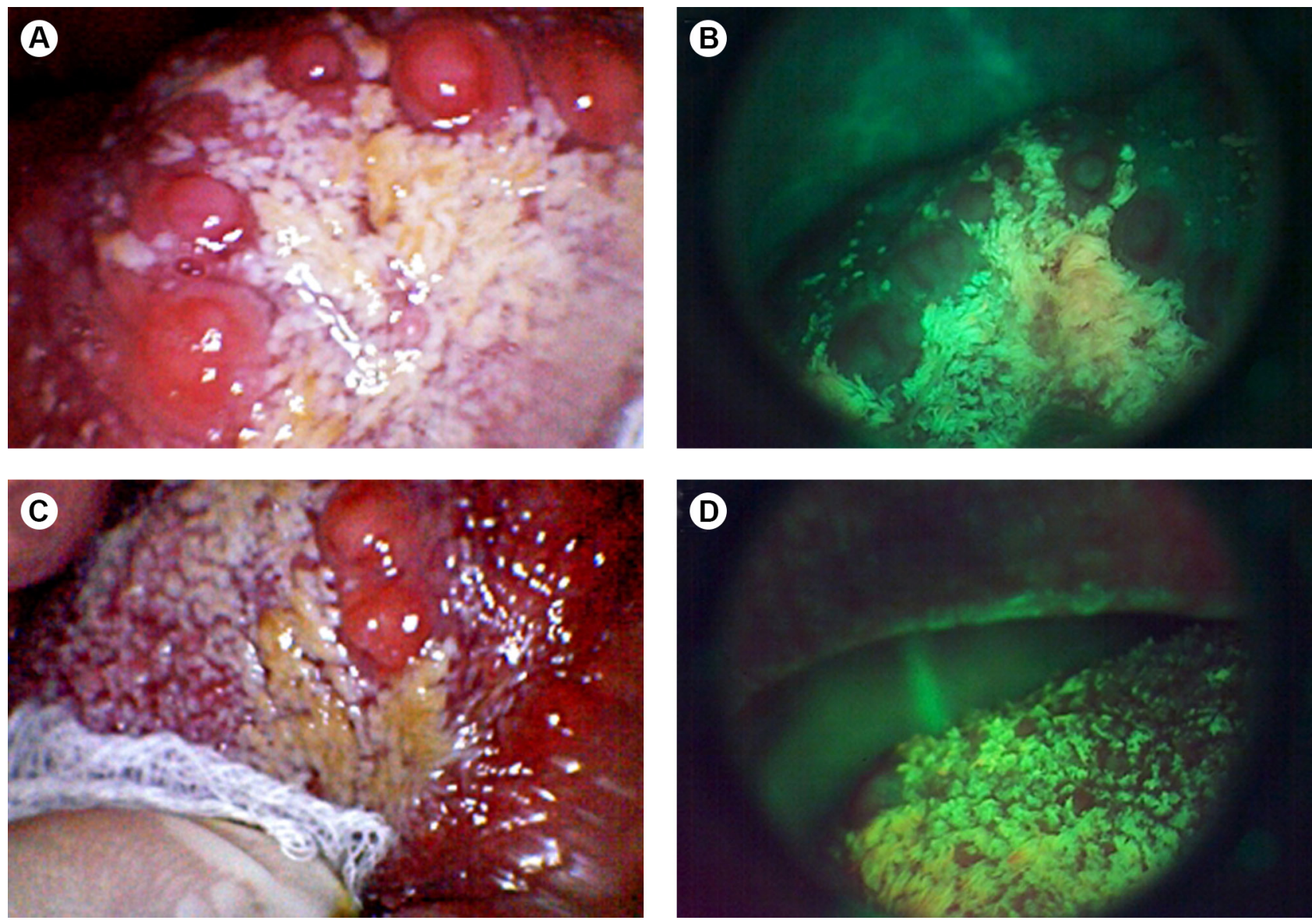

Figure 1. A: shows image of dorsal tongue surface, anterior to the papillae circumvallated, with presence of white plaque with some brownish areas. B: shows Widefield optical fluorescence image of lesion site where, can been see the projections of hairlike appearance with bright green fluorescence. C: image of dorsal tongue surface being scraped off with surgical gauze, resulting in reduction of the whitish aspect of the lesion due to tissue desquamation. D: Fluorescence image immediately after tongue scraping, with reduction of green fluorescence intensity in the lesion site, when compared with Panel B, due to the reduction of the keratinized layer. 
papillae in the region (Fig. 1C).

Subsequently, new fluorescence image was obtained where, real and immediate improvement of the lesion was observed, maintaining intense green appearance under fluorescence, but with less intensity and without the hairlike appearance found in figure 1B. Fungiform papillae region appears as points of lower fluorescence in the middle of the area of intense green fluorescence (Fig. 1D)

Since clinical images of dorsal tongue surface shows presence of white plaque with some brownish areas, which could be scraped (Fig. 1. A,C) and, fluorescence images show projections of hairlike appearance in tongue dorsal surface (Fig. 1. B,D), the final diagnosis, was established as hairy tongue.

The patient was advised on the benign nature of the lesion and, about the need to combat the predisposing factors, in this case, smoking and poor oral hygiene. Thus, the treatment consisted in promoting the desquamation of the hyperkeratotic papillae using lingual scraper and brushing of the dorsal tongue surface with soft toothbrush and toothpaste, performed by the patient. A follow-up appointment was scheduled for 30 days

After 30 days the patient reported not having implemented measures to reduce smoking and did not proceed to scraping and brushing of the tongue daily. Thus, improvement in clinical status was obtained previously with scraping by surgical gauze. Clinically, there was the persistence of areas with whitish and brownish plaques (Fig. 2A). Under fluorescence, the bright green appearance of the lesion remains, however, without projections with hairlike appearance. Sites with loss of fluorescence, with darkened images were not visualized (Fig. 2B). In turn, the patient was informed that the success of the treatment is dependent of scraping and lingual brushing. Thus, the patient was maintained with monthly follow-up with dentist specialist in oral diagnosis and, was implemented by general dental practitioner, a supervised oral hygiene program for the patient with weekly consultations.

\section{Discussion}

In this case, the clinical examination performed by both, general dental practitioner and dentist specialist in oral diagnosis, found a false positive result for oral cancer in a hairy tongue lesion. Otherwise, widefield optical fluorescence exam aided both to confirm the final diagnosis as hairy tongue and to differentiate between the diagnostic hypotheses presented by the general dental practitioner and the dentist specialist in oral diagnosis, which were squamous cell carcinoma and verrucous carcinoma. In this sense, Lane et al. (19) suggest that differential diagnosis in oral lesions is difficult even for specialists due to the clinical similarity, in the initial stages, of several oral pathologies (19). Indeed, Downer et al. (21) presented sensitivity data ranging from 59 to $97 \%$ and specificity of 75 to $99 \%$ that not guarantee to the professionals, through clinical examination, safety in discriminating between normal oral mucosa of lesion premalignant or cancer (21).

In the presented case of hairy tongue, the initial clinical image does not present a clear visualization of the classical appearance of hairlike projections, which may have originated the difficulty of clinical diagnosis. Such difficulty is because asymptomatic whitish plaques in smokers are a common feature not only of hairy tongue, but also of squamous cell carcinoma, oral hairy leukoplakia and premalignant leukoplakia. However, under fluorescence, the hair-like projections are clearly shown as a bright green carpet. Thus, the increase of keratin in the filiform papillae in hairy tongue leads to an increase of
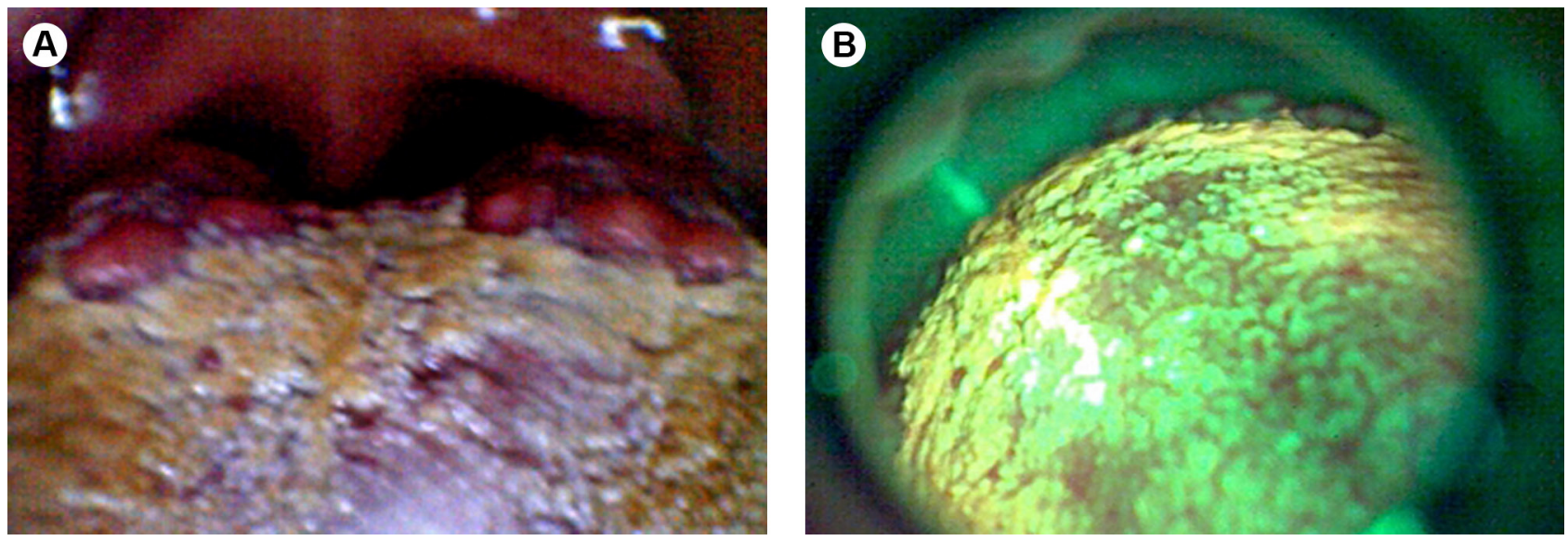

Figure 2. A: Clinical image with presence of white and brownish plaques on the dorsal tongue surface, anterior to the circumvallated papillae. B: Bright green appearance of the lesion under fluorescence due to hyperkeratinization of the filiform papillae. 
fluorescence visualization in bright green color, facilitating the differential diagnosis $(1,5,6,10,17-20,22)$. Keratin presents as the main fluorophore involved in this pathology, since, scraping the lesion to remove hyperkeratotic superficial layers implied in the reducing of visualization of the fluorescence intensity, even eliminating the hairlike appearance. It is noteworthy that the improvement provided by fluorescence examination when compared to the clinical examination in the perception of an oral pathology, as in the case presented, is even highlighted in the US FDA text for approval of the use of such fluorescence devices $(17,19,20)$.

Interestingly, the present case does not refer to a black hairy tongue, since there is no brown-black coloration of the tongue, which, other authors attributed to the presence of bacteria producing porphyrins on the tongue dorsal surface $(1,5,9)$. In this sense, Gillenwater et al. (23) and Roblyer et al. (24), in turn, report that the visualization of reddish fluorescence in the oral cavity may be related to the presence of porphyrins produced by bacteria $(18,23,24)$. Thus, as fluorescence image does not allow to visualize fluorescence aspects of reddish coloration and, the clinical image is of a Brownish-white Hairy tongue, this fact may be suggestive that, the Black coloration of a hayry tongue, really, can be due to the prophyrins presence.

In turn, most widefield fluorescence research adopts the premise that, a darkened area image with loss of fluorescence, may be suggestive of malignancy. Lane et al. (19) adopting this premise, reported sensitivity of 98\% and specificity of $100 \%$ to discriminate between normal mucosa and dysplasia or oral cancer (19). Thus, in this case, the absence of fluorescence images with darkened appearance due to loss of fluorescence, suggests the benign nature of the pathology.

In conclusion, the use of widefield optical fluorescence in an oral diagnostic routine can provide data and images, in real time and painlessly, that can help the professional to establish a correct diagnosis.

\section{Resumo}

A língua pilosa é uma patologia benigna, caracterizada clinicamente por placas hiperqueratinizadas na face dorsal da língua, semelhante a pelos, cuja coloração varia de despigmentada, esbranquiçada, amarelada, verde, acastanhada a preta. 0 diagnóstico é clínico, e em casos de placas esbranquiçadas, pode ser difícil diferenciar entre leucoplasia pilosa oral, leucoplasia potencialmente maligna ou carcinoma de células escamosas. Assim, o exame complementar de fluorescência óptica de campo amplo pode permitir uma melhor visualização do padrão local de hiperqueratinização semelhante à pelos, os quais são característicos de língua pilosa, facilitando o diagnóstico. Neste trabalho, um paciente do sexo masculino, 57 anos, foi encaminhado ao Departamento de Odontologia da Secretaria de Saúde de Divinópolis (Minas Gerais) por um clínico geral, visando o diagnóstico de uma possível lesão maligna na face dorsal da língua. 0 exame complementar por fluorescência óptica de campo amplo foi realizado. Para isso, foi empregado um dispositivo com diodo emissor de luz de alta potência, com luz centrada em um comprimento de onda de $(400 \pm 10)$ nm e irradiância máxima de $(0,04 \pm 0,008) \mathrm{W} / \mathrm{cm}^{2}$ para visualização de fluorescência. As imagens de fluorescência mostraram projeções de aparência semelhante à pelos na superficie dorsal da língua, sem aspectos de malignidade. A aparência similar à pelos é a principal característica da língua pilosa. Dessa maneira, o diagnóstico final foi estabelecido. Em conclusão, neste caso, o uso da fluorescência óptica de campo amplo permitiu um diagnóstico diferencial, sem a necessidade de uma biópsia incisional.

\section{Acknowledgements}

The authors thank FAPESP (São Paulo Research Foundation) (grant number: 2013/07276-1 (CEPOF); CNPq, FAPEMIG and CAPES for financial support and fellowships.

\section{References}

1. Mangold AR, Torgerson RR, Rogers RS. Diseases of the tongue. Clin Dermatol 2016;34:458-469.

2. Laskin D, Giglio J, Rippert E. Differential diagnosis of tongue lesions. Quintessence Int 2003;34:331-342.

3. Villa A, Woo S Bin. Leukoplakia-A Diagnostic and Management Algorithm. J Oral Maxillofac Surg 2017;75:723-34.

4. Warnakulasuriya S. Global epidemiology of oral and oropharyngeal cancer. Oral Oncol. 2009;45:309-316.

5. Gurvits GE, Tan A. Black hairy tongue syndrome. World J Gastroenterol 2014;20:10845-10850.

6. Reamy B V, Derby R, Bunt CW. Common tongue conditions in primary care. Am Fam Physician 2010;81:627-634.

7. Korber A, Dissemond J. Black Hairy Tongue. N Engl J Med 2006 5;354:67-67.

8. Newman CC, Wagner RF. Images in clinical medicine. Black hairy tongue. N Engl J Med 1997;337:897.

9. Ramsakal A, Mangat L. Images in clinical medicine. Lingua villosa nigra. N Engl J Med 2007;357:2388.

10. Patil S, Kaswan S, Rahman F, Doni B. Prevalence of tongue lesions in the Indian population. J Clin Exp Dent 2013;5:e128-e132.

11. Van der Waal I. Oral leukoplakia, the ongoing discussion on definition and terminology. Med Oral Patol Oral Cir Bucal 2015;20:e685-e692.

12. Martins LL, Rosseto JHF, Andrade NS, Franco JB, Braz-Silva PH, Ortega KL. Diagnosis of Oral Hairy Leukoplakia: The Importance of EBV In Situ Hybridization. Int J Dent 2017;2017:3457479.

13. Parlatescu I, Gheorghe C, Coculescu E, Tovaru S. Oral leukoplakia - an update. Mædica 2014;9:88-93.

14. Van Der Waal I, Schepman KP, Van Der Meij EH, Smeele LE. Oral leukoplakia: A clinicopathological review. Oral Oncol 1997;33:291301.

15. Kraus FT, Perezmesa C. Verrucous carcinoma. Clinical and pathologic study of 105 cases involving oral cavity, larynx and genitalia. Cancer 1966;19:26-38.

16. Hassona Y, Scully C. Verrucous Tongue Lesion. N Engl J Med 2015;372:2049.

17. Shin D, Vigneswaran N, Gillenwater A, Kortum RR. Advances in fluorescence imaging techniques to detect oral cancer and its precursors. Futur Oncol 2010;6:1143-1154.

18. Andrade SA, Pratavieira S, Ribeiro MM, Bagnato VS, de Pilla Varotti F. Oral cancer from the perspective of wide-field optical fluorescence: Diagnosis, tumor evolution and post-treatment follow up. Photodiagnosis Photodyn Ther 2017;:239-242.

19. Lane PM, Gilhuly T, Whitehead P, Zeng H, Poh CF, Ng S, et al. Simple device for the direct visualization of oral-cavity tissue fluorescence. J Biomed Opt 2006;11:024006.

20. Andrade SA, de Pilla Varotti F, Bagnato VS, Pratavieira S. Firearm projectile in the maxillary tuberosity located by adjunctive examination of wide-field optical fluorescence. Photomed Laser Surg 2018;36:112-115.

21. Downer MC, Moles DR, Palmer S, Speight PM. A systematic review 
of test performance in screening for oral cancer and precancer. Oral Oncol 2004;40:264-273.

22. Manabe M, Lim HW, Winzer M, Loomis CA. Architectural organization of filiform papillae in normal and black hairy tongue epithelium: dissection of differentiation pathways in a complex human epithelium according to their patterns of keratin expression. Arch Dermatol. 1999;135:177-181.

23. Gillenwater AM, Jacob R, Ganeshappa $R$, Kemp B, El-Naggar AK, Palmer JL, et al. Noninvasive diagnosis of oral neoplasia based on fluorescence spectroscopy and native tissue autofluorescence. Arch Otolaryngol Neck Surg 1998;124:1251.

24. Roblyer D, Kurachi C, Stepanek V, Williams MD, El-Naggar AK, Lee $\mathrm{JJ}$, et al. Objective detection and delineation of oral neoplasia using autofluorescence imaging. Cancer Prev Res 2009;2:423-431.

Received June 28, 2018 Accepted August 18, 2018 